\title{
ETHIOPIAN POLITICAL CULTURE STRIKES BACK: A REJOINDER TO J. ABBINK
}

\author{
Tobias HagmanN
}

IN HIS ARTICLE ON THE MAY 2005 ETHIOPIAN PARLIAMENTARY ELECTIONS, J. Abbink sets out to explain 'why the political system has stagnated and slid back into authoritarianism'. 'According to Abbink, the 2005 elections and their aftermath have led to the resurgence of an Ethiopian 'authoritarian political tradition' (p. 173). The driving factor behind this, so he argues, is the 'patrimonialized system' (p. 177) in which power holders treat the country and politics as their 'privileged domain' (p. 196). Neo-patrimonial rule by the Ethiopian People's Revolutionary Democratic Front (EPRDF) government of Prime Minister Meles Zenawi is animated by different factors, among them 'resource competition' and an unwillingness 'to let go of power' (p. 196). All these political processes are embedded in 'certain relatively unchanging structures and notions in Ethiopian politics' (p. 178) that Abbink subsumes under the notion of political culture. His article concludes by observing a continuity of 'violent succession problems in the Ethiopian political system' (p. 198) from the eleventh century to today. The shortcomings of this argument can be grouped under three headings. The first relates to Abbink's improvident use of the catch-all concepts political culture and neo-patrimonialism. Second, the article contains methodological inconsistencies that weaken its principal propositions. Finally, I call into question the author's teleological conclusion and outline elements for an alternative interpretation of the 2005 Ethiopian elections based on a political rather than a culturalist understanding of politics.

\section{Catch-all concepts}

Much of Abbink's reasoning rests on the idea of (Ethiopian) political culture, which is supposed to account for the EPRDF's performance during the 2005 elections and, more generally, for a historic continuity of political authoritarianism in Ethiopia. 'Ethiopian political culture', so Abbink determines, 'is not yet free from its historical heritage of authoritarianism, elite

Tobias Hagmann (tobias.hagmann@swisspeace.ch) is a researcher at the Swiss Peace Foundation, Bern, and a doctoral student at the Swiss Graduate School of Public Administration (IDHEAP), University of Lausanne.

1. J. Abbink, 'Discomfiture of democracy? The 2005 election crisis in Ethiopia and its aftermath', African Affairs 105,419 (2006), p. 173. 
rule, and patronage' (p. 193). In the past four decades, political scientists have harshly criticized political culture both as a concept and as an independent variable. ${ }^{2}$ Authors have emphasized the indeterminacy of the concept, its lack of operational definition, its inability to explain political change and its psychological reductionism. ${ }^{3}$ Abbink uses political culture as an umbrella concept without spelling out the ontological or empirical dimensions that it is thought to encapsulate. In the absence of definitional clarification and delimitation, his approach to political culture is obscure. The study of political culture must be based on a comparison of different units of analysis (differentiated by time, place or specific levels of social aggregation such as a nation, a group or a city). Consequently, his depiction of Ethiopian political culture evokes a conception of a national Ethiopian character that does not exist. The article ominously refers to an 'old grid of autocratic governance' that 'was resurrected' (p. 193) but remains silent on the actors who embody and the concrete strategies that led to this 'resurrection'. One gains the impression that Ethiopia in 2005 all of a sudden succumbed to an ancient political culture that struck the country like a thunderbolt. The reader would like to know which social entity is supposed to embody 'Ethiopian political culture' and, ultimately, is responsible for blockading democratization. Does Abbink assume a common political culture of all Ethiopian citizens, irrespective of the impressive social, economic, ethnic and religious diversity of the country? ${ }^{4}$ Or does he refer exclusively to the political culture of the ruling EPRDF party? Is Ethiopian political culture primarily located in the state or rather in society, or eventually in both? Does each ethnic group have its own political culture, and if yes, how do they relate to each other? All these fundamental questions remain unanswered. Abbink's references to political culture are primordialist. Rather than conceiving political culture as a repertoire that offers a 'range of acceptable possible alternatives from which groups or individuals may (...) choose a course of action', ${ }^{5}$ the author reduces political culture to a set of fixed attitudes such as the above-mentioned 'authoritarianism, elite rule and patronage' (p. 193).

2. The concept 'political culture' originates in American behavioural political science of the 1950s and 1960s. It was first popularized in Gabriel A. Almond and Sidney Verba, The Civic Culture: Political attitudes and democracy in five nations (Princeton University Press, Princeton, 1963). For a comprehensive review of the evolving debate and subsequent critiques of political culture see Ronald P. Formisano, 'The concept of political culture', Fournal of Interdisciplinary History 31, 3 (2000), pp. 393-426.

3. Lowell Dittmer, 'Political culture and political symbolism: toward a theoretical synthesis', World Politics 29, 4 (1977), p. 552; Harry Eckstein, 'A culturalist theory of political change', American Political Science Review 82, 3 (1988), pp. 789-804; Ruth Lane, 'Political culture: "residual category or general theory?" ', Comparative Political Studies 25, 3 (1992), p. 362.

4. Folk discourse of Ethiopian 'authoritarian' culture usually draws upon the idea of 'Amhara political culture' as developed in Donald L. Levine, 'Ethiopia: identity, authority, and realism', in Lucian W. Pye and Sidney Verba (eds), Political Culture and Political Development (Princeton University Press, Princeton, 1965), pp. 245-81.

5. David J. Elkins and Richard E. B. Simeon, 'A cause in search of its effect, or what does political culture explain?’, Comparative Politics 11, 2 (1979), p. 131. 
Abbink's intention to go beyond 'formal political science approaches' (p. 176) is laudable, and neo-patrimonialism provides such an alternative heuristic framework. However, given the heterogeneity of the neo-patrimonial literature, the latter must be contextualized, defined and operationalized to become truly meaningful. A critical engagement with neo-patrimonial theory is necessary if we want to make it prolific for a specific research context. Among the key features of neo-patrimonial rule in post-1991 federal Ethiopia are the co-existence of patrimonial and legal-rational domination, institutional instability at administrative level, and complex and often contradictory patron-client relations. ${ }^{6}$ The 2005 parliamentary elections, appointments of local and regional bureaucrats, policy formulation and implementation or federal-regional interactions all operate at the interface of these three elements of Ethiopian neo-patrimonialism. Unfortunately, Abbink's interpretation of neo-patrimonialism suffers from analogous shortcomings as his treatment of political culture. He does not elaborate distinctive patterns of neo-patrimonial rule theoretically or empirically but presents neo-patrimonialism as a self-explanatory and all-encompassing fact. It is not sufficient to refer to 'circles and networks of a neo-patrimonialist nature' (p. 178) without articulating who exactly enacts neo-patrimonial domination, by which means and with which outcomes. Who are the patrons and clients of EPRDF's neo-patrimonial system? What are the material and symbolic benefits that patronage politics produce? How are these benefits distributed among and between the political elite, the urban middle class and the rural masses? Do modern political parties such as EPRDF and the Tigray People's Liberation Front (TPLF) truly represent a 'personalized' and 'traditionalist' form of domination in the sense of Médard's (1996) understanding of neo-patrimonialism to which Abbink subscribes (p. 175)? $?^{7}$ These are the kinds of questions that a neo-patrimonial analysis should scrutinize and which the author again leaves unanswered. Finally, Abbink's presentation of coercion as a typical strategy of a contested political system breaks no secrets either. ${ }^{8}$

\section{Methodological problems}

There is a glaring disconnect between the article's sweeping generalizations and the actual empirical material that supports them. Abbink alleges that the EPRDF's reluctance to concede power to the opposition parties and

6. Tobias Hagmann, 'Beyond clannishness and colonialism: understanding political disorder in Ethiopia's Somali Region, 1991-2004', Fournal of Modern African Studies 43, 4 (2005), pp. 509-36.

7. Jean-François Médard, 'Patrimonialism, neo-patrimonialism and the study of the postcolonial state in Subsaharan Africa', in H.S. Marcussen (ed.), Improved Natural Resource Management - the role of formal organisations and informal networks and institutions (Institute of International Development Studies, Roskilde University, Roskilde, 1996), pp. 76-97.

8. See Hagmann, 'Beyond clannishness', p. 532. 
its increasingly autocratic rule result from a neo-patrimonial logic embedded in an authoritarian political culture. Half of the article is devoted to an empirical account of events immediately before, during and after the May 2005 elections. This section is diligently written but limited to a time span of one year and to political developments in the formal political arena. It does not explain how neo-patrimonialism shaped the course of elections nor does it spell out the practices and meanings of political culture in Ethiopia. Abbink preaches historicity and a broad approach to transition politics but practices oblivion in regard to the past and his own principles. He repeatedly emphasizes the need for a more historical analysis that considers 'the wider political and historical context' (pp. 175-176) of the 2005 elections. At the same time, he contents himself with a half-page summary of pre1991 Ethiopian history. The author declares the necessity of taking into account 'class power, civil society groups, the stature and power (capacity) of the state, and transnational political connections' (p. 174) yet provides at best anecdotal evidence of their importance during elections. Likewise, the nexus between economic interests and political power is alleged but not demonstrated. None of these omissions are dramatic by themselves were the author not to ascribe them a major explanatory role in his argumentation. As a result, the empirical description of the 2005 elections remains disjointed both from the grandiose introduction and from the broad-brush statements found in the concluding sections.

Furthermore, the author replaces one explanatory variable with the other at will. He first posits the enduring relevance of 'neo-patrimonial theory' (p. 175) to explain African political systems. A little later, the article pleads for 'a view of politics in more cultural terms, taking into account ethnic/kinship networks, local conceptions and psychologies of power, the role of ideology, and (informal) business interests' (p. 176). Next, it is resource competition that 'although not explaining all, goes a long way in accounting for Ethiopia's exclusivist and conflictual political dynamics' (p. 178). Finally, the author refers to the 'historic burden of violence used as a political means' (p. 179) to elucidate Ethiopian politics. Abbink piles up these multiple explanations without expounding a single one of them with the empirical depth or analytical clarity they deserve. Neither does he discuss the correlations between them. The reader is left in the dark about which of these factors are thought to explicate the authoritarian turn of nascent multi-party democracy in Ethiopia. Commonsensical statements such as 'in Ethiopia, politics is a game where the stakes are high' (p. 180) hardly compensate for this lacuna.

Abbink rightly criticizes earlier works on Ethiopian politics that privileged an assessment of formal institutions over an investigation into political practices and power relations. This research tradition has often centred on a normative discussion of if and to what degree the Federal Democratic Republic of Ethiopia has become (more) democratic compared with its 
predecessors and with other African regimes. ${ }^{9}$ However, the author ignores many existing scholarly contributions that have gone beyond legal and formal considerations of Ethiopian politics. Lovise Aalen, Edmond J. Keller, Siegfried Pausewang, Kjetil Tronvoll, Sarah Vaughan and others have long before the 2005 elections - demonstrated the predominance of a centralized and authoritarian EPRDF party system that operates behind the facades of federalism and ethno-national self-determination. ${ }^{10}$

\section{Teleology and alternative explanations}

The culmination of Abbink's flawed argumentation is his final statement about the 'remarkable but tragic continuity of Ethiopian history' (p. 198). This conclusion is highly problematic. Philosophically, it connotes the erroneous idea that (Ethiopian) history is predetermined. The author's initial intention of developing 'a view of politics in more cultural terms' (p. 176) here reverts to the kind of culturalism that 'overlooks contradiction and political conflict as factors'. ${ }^{11}$ The image of a stable and monolithic Ethiopian polity and identity is ahistoric. It reflects a prevailing mindset in the mainstream of Ethiopian studies, which are caught in what Clapham termed 'the great tradition': a teleological belief in the glorious continuity of the (highland Orthodox Christian) Ethiopian state and civilization. The major weakness of the 'great tradition' is its failure to acknowledge 'the historically very variable territoriality of that state, and of the great variety of alternative political arrangements that have co-existed with it'. ${ }^{12}$ Abbink simply blends out the events and processes that do not suit his ex post reading of the 2005 elections as a resurgence of authoritarian political tradition. At no point in recent Ethiopian history were political events predetermined and the gap between political parties' calculations before 15 May 2005 and the actual election results provides the best illustration for this. The EPRDF was clearly taken by surprise by the massive loss of votes it incurred in rural areas of Amhara, Oromiya and Southern regions. Likewise, the

9. A typical example of such thinking is the debate, 'Is Ethiopia democratic?' featured in the Fournal of Democracy 9,4 (1998). While Paul B. Henze designates federal Ethiopia as a 'political success story', Richard Joseph and John W. Harbeson strongly contradict this view.

10. Lovise Aalen, Ethnic Federalism in a Dominant Party State: The Ethiopian experience 19912000 (Chr. Michelsen Institute, Bergen, 2002); Edmond J. Keller, 'Ethnic federalism, fiscal reform, development and democracy in Ethiopia', African fournal of Political Science 7,1 (2002), pp. 21-50; Siegfried Pausewang, 'Ethiopia: crisis of state, good governance and the reform of the security sector' in Tobias Debiel and Axel Klein (eds), Fragile Peace: State failure, violence and development in crisis regions (Zed Books, London, 2002), pp. 171-88; Sarah Vaughan and Kjetil Tronvoll, The Culture of Power in Contemporary Ethiopian Political Life (Sida, Stockholm, 2003).

11. Jean-François Bayart, The Illusion of Cultural Identity (University of Chicago Press, Chicago, 2005), p. 14.

12. Christopher Clapham, 'Rewriting Ethiopian history', in Centre Français d'Études Éthiopiennes (ed.), Annales d'Éthiopie (Editions Table Ronde, Addis Ababa, 2002), p. 41. 
opposition Coalition for Unity and Democracy (CUD) condemned the polling on election day in ignorance of the impressive electoral gains it had just achieved. Later on, the decision by CUD's executive committee in October 2005 to boycott the House of People's Representatives and to refuse taking over the Addis Ababa city administration was strongly contested by its representatives and sympathizers. These cursory examples demonstrate that political developments before and after the May 2005 elections were neither predictable nor predetermined. Considered from a moral perspective, Abbink's lament about the continuity of Ethiopian history is, so I assume, meant to express empathy with Ethiopians. Those who equate human existence to a Greek drama might feel comforted by such a fatalistic conclusion. Others might feel that, by designating Ethiopian history as a 'tragedy', Abbink unintentionally excuses rather than sociologically explains authoritarian rule by the EPRDF government.

This leads me to the last point. How can we explain contemporary Ethiopian politics and in particular last year's elections? While a fullfledged analysis is beyond the scope of this rejoinder, I propose some avenues for fruitful engagement from the perspective of political sociology. ${ }^{13}$ First, there is a need to unravel the complex mechanisms of control, cooptation and resistance that characterize interactions between political constituencies in contemporary Ethiopia. An analysis of political parties, elite and ordinary citizens' strategies to accomplish political representation and further collective interests within and outside of the formal political arena is required. The 2005 elections provided such an occasion as they allowed large parts of Ethiopian society to contest the existing political order. One question to ponder is how individuals and communities who had so far been acquiescent to the regime's rule enacted resistance towards the government. A similar question relates to how the opposition parties mobilized dissent in a political system characterized by EPRDF's formidable bureaucratic control that reaches from the federal palace down to rural kebeles. ${ }^{14}$ Second, it is imperative to look at electoral politics beyond the simple confrontation between government and opposition. Area study scholars in general, and Ethiopianists in particular, tend to ignore the web of transnational relations in which national politics are located. In the Ethiopian case, one cannot understand domestic politics without taking into account its protracted relations with Eritrea, the role of the worldwide Ethiopian diaspora, enormous financial support provided by international donors and the fact that Ethiopia is a major partner in the 'war against

13. A vivid analysis of the 2005 Ethiopian elections is provided by Christopher Clapham, 'Comments on the Ethiopian crisis', 14 November 2005, <http://www.ethiomedia.com/fastpress/ clapham_on_ethiopian_crisis.html> (26 December 2005).

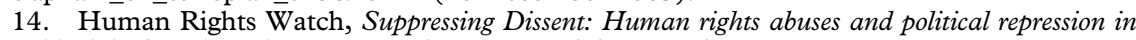
Ethiopia's Oromia region (New York, Human Rights Watch, 2005). 
terror' led by the United States. Geopolitics and electoral politics cannot be kept apart artificially. Donor countries' choice to uphold close relations with the EPRDF regardless of the human rights violations committed by government forces in June and November 2005 demonstrates the blatant hypocrisy of Western countries and the considerable weight the regime enjoys internationally. ${ }^{15}$

Finally, studies on 'democratization' in Ethiopia and elsewhere in Africa would benefit from a heavy dose of reflexivity on behalf of researchers. Rather than assessing elections against the backdrop of a presumed universal model of liberal democracy, academics should abandon the positivist idea that democracy is something that can be measured. Alternatively, the instrumental uses that domestic and foreign actors make of 'democracy' and the highly politicized processes by which a practice is declared 'democratic' should be at the centre of our attention. In the Ethiopian case, this implies that scholars are careful in the way they represent intensive political struggles such as the 2005 elections, that they avoid well-meant propositions about how citizens are supposed to behave in politics ${ }^{16}$ and that they provide explanations centred on human agency, not divine destiny.

\section{Bibliography of books and articles}

References to other sources, including interviews, archives, newspaper articles, websites and grey publications, are contained in relevant footnotes.

Aalen, L., Ethnic Federalism in a Dominant Party State: The Ethiopian experience 1991-2000 (Chr. Michelsen Institute, Bergen, 2002).

Abbink, J., 'Discomfiture of democracy? The 2005 election crisis in Ethiopia and its aftermath', African Affairs 105, 419 (2006), pp. 173-99.

Almond, G.A. and S. Verba, The Civic Culture: Political attitudes and democracy in five nations (Princeton University Press, Princeton, 1963).

Bayart, J.-F., The Illusion of Cultural Identity (University of Chicago Press, Chicago, 2005).

Clapham, C., 'Rewriting Ethiopian history', in Centre Français d'Études Éthiopiennes (ed.), Annales d'Éthiopie (Editions Table Ronde, Addis Ababa, 2002), pp. 37-54.

Dittmer, L., 'Political culture and political symbolism: toward a theoretical synthesis', World Politics 29, 4 (1977), pp. 552-83.

15. Donor countries mostly articulated mild or no criticism towards the Ethiopian government following these events. A typical example is the British Department for International Development (DFID) which announced a suspension of bilateral direct budgetary suppnrt in the order of 40 million pounds sterling in January 2006, only to announce in June 2006 a 94 million pounds sterling contribution to a World Bank health, water and education programme, to be implemented with local government. See 'Ethiopia: Suspended funding redirected to poverty alleviation', IRIN, 29 May 2006, <http://www.irinnews.org/report.asp? ReportID=53575\&SelectRegion=Horn_of_Africa\&SelectCountry=ETHIOPIA > (20 June 2006). 16. Such as Donald Levine who suggested that 'all Ethiopians need to learn to listen and talk to one another in a respectful manner', letter by Donald Levine to Ethiopian Ambassador to the United States of America Kassahun Ayele, 28 September 2005, <http://www.ethioindex.com/ lela/univchicago.htm> (21 October 2005). 
Eckstein, H., 'A culturalist theory of political change', American Political Science Review 82, 3 (1988), pp. 789-804.

Elkins, D.J. and R.E.B. Simeon, 'A cause in search of its effect, or what does political culture explain?', Comparative Politics 11, 2 (1979), pp. 127-45.

Formisano, R.P., 'The concept of political culture', fournal of Interdisciplinary History 31, 3 (2000), pp. 393-426.

Hagmann, T., 'Beyond clannishness and colonialism: understanding political disorder in Ethiopia's Somali Region, 1991-2004', fournal of Modern African Studies 43, 4 (2005), pp. 509-36.

Harbeson, J.W., 'A bureaucratic authoritarian regime', fournal of Democracy 9, 4 (1998), pp. 62-9.

Henze, P.B., 'A political success story', fournal of Democracy 9, 4 (1998), pp. 40-54.

Joseph, R., 'Oldspeak vs. newspeak', Fournal of Democracy 9, 4 (1998), pp. 55-61.

Keller, E.J., 'Ethnic federalism, fiscal reform, development and democracy in Ethiopia', African fournal of Political Science 7, 1 (2002), pp. 21-50.

Lane, R., 'Political culture: "residual category or general theory?" ', Comparative Political Studies 25, 3 (1992), pp. 362-87.

Levine, D.L., 'Ethiopia: identity, authority, and realism', in L.W. Pye and S. Verba (eds), Political Culture and Political Development (Princeton University Press, Princeton, 1965), pp. 245-81.

Médard, J.-F., 'Patrimonialism, neo-patrimonialism and the study of the postcolonial state in Subsaharan Africa', in H.S. Marcussen (ed.), Improved Natural Resource Management - the role of formal organisations and informal networks and institutions (Institute of International Development Studies, Roskilde University, Roskilde, 1996), pp. 76-97.

Pausewang, S., 'Ethiopia: crisis of state, good governance and the reform of the security sector', in Tobias Debiel and Axel Klein (eds), Fragile Peace: State failure, violence and development in crisis regions (Zed Books, London, 2002), pp. 171-88. 